\title{
EFEKTIVITAS SENYAWA SULFIDA PADA BAWANG PUTIH TERHADAP RESIKO KANKER PARU-PARU
}

\section{Effectiveness Of Sulfid Compounds On Garlic Towards The Lung Cancer Risk}

\author{
Connie Daniela ${ }^{1 *}$, Desni Siliawati Br Brahmana ${ }^{2}$ \\ ${ }^{1}$ Program Studi Teknologi Hasil Pertanian Unika Santo Thomas Medan \\ ${ }^{2}$ Program Studi Ilmu dan Teknologi Pangan Universitas Sumatera Utara
}

*Koresponden E-mail : delasimbolon16@gmail.com

DOI: https://doi.org/10.32382/mf.v16i2.1685

\section{ABSTRACT}

Lung cancer is a degenerative disease caused by smoking, and one of the phytochemical in garlic compound have the potentials to suppress the lung cancer proliferation due to the cigarette carcinogens induction, such as acrylamide. This research aims to study the effectiveness of simple and compound garlic as an anticancer through in vivo testing with acrylamide induction at a dose of $50 \mathrm{mg} / \mathrm{kgBW}$ (4 days) and subsequent garlic extract at a dose of $1000 \mathrm{mg} / \mathrm{kgBW}$ on experimental mice (14 days). The results showed that compound garlic was able to suppress the lung cancer cells proliferation at a damage degree of 1 without any death during the study.

Keywords : Anti-cancer, Acrylamide, Garlic, Cell Proliferation

\section{ABSTRAK}

Kanker paru-paru merupakan penyakit degeneratif yang dapat disebabkan oleh kebiasaan merokok. Salah satu senyawa fitokimia bawang putih terbukti dapat menekan proliferasi kanker paru-paru akibat induksi senyawa karsinogen rokok, yaitu akrilamida. Penelitian ini bertujuan untuk mempelajari efektivitas bawang putih tunggal dan majemuk sebagai antikanker melalui pengujian in vivo dengan induksi akrilamida dosis $50 \mathrm{mg} / \mathrm{kgBB}$ (4 hari) kemudian diberikan ekstrak bawang putih dosis $1000 \mathrm{mg} / \mathrm{kgBB}$ mencit percobaan (14 hari). Hasil penelitian menunjukkan bahwa bawang putih majemuk mampu menekan proliferasi sel kanker paru-paru pada derajat kerusakan skor 1 tanpa ada kematian mencit selama penelitian.

Kata kunci : Anti kanker, Akrilamida, Bawang Putih, Proliferasi Sel

\section{PENDAHULUAN}

Indonesia merupakan salah satu Negara surga perokok dan menurut perkiraan WHO, situasinya akan memburuk 10 tahun ke depan. Dalam laporan tahunannya, dicatat $36 \%$ atau sekitar 60 juta orang penduduk Indonesia merokok. WHO menempatkan rokok ke dalam daftar utama pemicu mematikan seperti kanker paru-paru (Deutsche Welle, 2015).

Asap rokok telah terbukti merupakan penyebab utama timbulnya kanker paru, baik pada perokok aktif maupun pasif. Angka kesakitan dan kematian akibat kanker paru meningkat sebanding dengan jumlah rokok yang dihisap setiap hari serta tingginya zat-zat karsinogen dalam tar pada asap rokok. Asap rokok dengan senyawa aktif senyawa tar dan nikotin, akan mengalami reaksi-reaksi yang bermula dari masuknya asap rokok dalam alveolus paru-paru dan memberikan pengaruh negatif pada gelembung paru-paru (Seyedzadeh et $a l, 2012$ ).
Bawang putih termasuk golongan tanaman herba parenial yang membentuk umbi lapis mengandung lebih dari 100 metabolit sekunder yang secara biologis sangat berguna (Yee, 2019).

Salah satu bentuk senyawa aktif pada bawang putih adalah allicin (diallyl tiosulfonate atau diallyl disulfide) (Lisiswanti dan Haryanto, 2017), berpotensi sebagai antioksidan utama dalam umbi bawang putih yang dapat menekan produksi nitrat oksida (NO) melalui 2 jalur, yakni pada konsentrasi rendah $(10 \mu \mathrm{M})$, menghambat kerja enzim cytokine-induced NO synthase (iNOS) (Liu et al., 2014). Jika perokok aktif maupun perokok pasif terpapar asap rokok yang mengandung zat-zat karsinogenik senyawa golongan sulfida pada bawang putih ini diharapkan dapat meminimalisir resiko terkena kanker paru-paru.

Bawang putih memiliki perbedaan berdasarkan jumlah umbinya, yaitu majemuk (satu tanaman lebih dari satu umbi) dan tunggal 
(satu tanaman satu umbi), oleh karena itu, penelitian ini bertujuan untuk mengetahui pengaruh jumlah umbi bawang putih terhadap komponen sulfida dan efektifitasnya terhadap resiko kanker paru-paru.

\section{METODE}

\section{Waktu dan Lokasi Penelitian}

Penelitian ini telah dilakukan pada pada bulan September 2019 sampai Desember 2019 di Laboratorium Struktur Fisiologi Hewan Fakultas MIPA Universitas Sumatera Utara.

\begin{abstract}
Alat dan Bahan
Alat-alat yang digunakan adalah blender (Philips HR 2116), gelas ukur (Pyrex), dan oven (Memmert UN 30), erlenmeyer (Pyrex), shaker (Oregon KJ201BD), rotary evaporator (B-ONE RE 1000VN), GCMSQP2010 SE (Shimadzu), dan kolom kapiler type Agilent 19091S-433 HP-5MS. Bahan yang digunakan adalah bawang putih berumbi majemuk dan berumbi tunggal yang diperoleh dari pasar tradisional di Berastagi, Sumatera Utara. Hewan uji mencit (Mus musculus), etanol teknis, akuades, etanol p.a, dan akrilamida.
\end{abstract}

\section{Populasi dan Sampel}

Populasi dalam penelitian ini adalah mencit yang sehat dengan berat badan antara 2535 gram. Sampelnya adalah mencit jantan (Mus musculus) yang sehat.

\section{Teknik Pengumpulan Data}

Data yang dikumpulkan adalah data berupa primer dari hasil pengamatan hewan coba, baik kelompok kontrol positif maupun kelompok kontrol negatif perlakuan. Data kualitatif yang diperoleh berupa warna paruparu, histologis alveolus, dan histologis paruparu mencit.

\section{Prosedur Kerja}

Penyiapan Bahan Uji

Bawang putih berumbi majemuk dan berumbi tunggal yang diperoleh dari pasar tradisional di Berastagi, Sumatera Utara.

\section{Pembuatan bubuk dan ekstrak bawang putih} Pembuatan bubuk bawang putih diawali dengan pengupasan dan pencucian bawang, kemudian ditambahkan akuades dengan perbandingan 1:1, diblender sampai bawang putih halus. Dikeringkan bawang putih yang telah halus di dalam oven dengan suhu $40^{\circ} \mathrm{C}$ selama 48 jam. Setelah kering, dihaluskan kembali dengan blender sehingga diperoleh bubuk bawang putih.
Pembuatan ekstrak dilakukan dengan terlebih dahulu menimbang $300 \mathrm{~g}$ bubuk bawang putih dipindahkan ke dalam beaker glass dan ditambahkan 1,8 liter etanol teknis (1:6), kemudian diaduk, ditutup menggunakan plastik polietilen dan di shaker selama 10 jam hingga terbentuk campuran etanol-bawang putih disaring dan hasil saring ditambahkan etanol teknis kembali, dishaker selama 10 jam (maserasi II) dan dilakukan maserasi III dengan cara yang sama.

Campuran etanol-bawang putih diekstraksi dengan rotary evaporator hingga dihasilkan ekstrak dan residu. Serta hasil ekstrak dari rotary evaporator tersebut diencerkan dengan akuades sehingga diperoleh konsentrasi $500 \mathrm{mg} / \mathrm{kgBB}$ dan $1000 \mathrm{mg} / \mathrm{kgBB}$ yang kemudian diberikan ke mencit percobaan (Nawangsih et al. 2015).

\section{Analisa golongan sulfida}

Bubuk bawang putih ditimbang sebanyak $10 \mathrm{~g}$, dimasukkan ke dalam beaker glass dan ditambahkan etanol p.a dengan perbandingan 1:2 (20 ml), lalu didiamkan selama 24 jam. Larutan dipisahkan sehingga diperoleh filtrat. Diambil $10 \mathrm{ml}$ filtrat dan diinjeksi ke GCMS-QP2010 Ultra Shimadzu menggunakan kolom kapiler type Agilent 19091S-433 HP5MS, dengan fase diam phenyl methyl sylox dan fase gerak adalah Helium dengan suhu kolom $270^{\circ} \mathrm{C}$.

Detektor MS memakai pengaturan suhu secara menit bertingkat (interface) yaitu $10^{\circ} \mathrm{C} /$ menit sampai $250^{\circ} \mathrm{C}$ menggunakan split injeksi dengan rasio 5:1 dan laju air gas 15 $\mathrm{ml} /$ menit. Kemudian diidentifikasi kandungan golongan sulfida yang terdapat pada bubuk bawang putih berumbi majemuk dan tunggal (Lagnado, 2001).

Perlakuan pada mencit menggunakan

2 jenis larutan, yaitu larutan akrilamida dengan dosis $50 \mathrm{mg} / \mathrm{kgBB}$ dan larutan esktrak etanol bawang putih dengan dosis $500 \mathrm{mg} / \mathrm{kgBB}$ dan $1000 \mathrm{mg} / \mathrm{kgBB}$. Pada pembuatan larutan ditambahkan 1\% Na-CMC, larutan dibuat tergantung pada berat badan rata-rata mencit dan volume pemberian, maka sebelum pemberian larutan dilakukan penimbangan berat badan dan volume pemberian larutan pada tiap mencit adalah $0,4 \mathrm{ml}$.

\section{Pengujian in vivo pada mencit percobaan}

Sampel terdiri atas 36 ekor mencit jantan (Mus Musculus) dipilih dengan cara random sampling untuk dibagi dalam satu 
kelompok negatif, satu kelompok kontrol positif, dan empat kelompok perlakuan. Setiap kelompok terdiri dari 6 ekor mencit dengan penjelasan sebagai berikut:

- Kelompok kontrol $(\mathrm{K})=$ Pemeliharaan selama 22 hari

- Kelompok Negatif (K-) = Pemberian akrilamida sebanyak $50 \mathrm{mg} / \mathrm{kgBB}$ selama 4 hari dan dipelihara selama 18 hari

- Kelompok Perlakuan $\left(\mathrm{K}_{1}\right)=$ Pemberian akrilamida sebanyak $50 \mathrm{mg} / \mathrm{kgBB}$ selama 4 hari dan dipelihara selama 4 hari, kemudian diberi ekstrak bawang putih berumbi majemuk sebanyak $500 \mathrm{mg} / \mathrm{kgBB}$ selama 14 hari

- Kelompok Perlakuan $\left(\mathrm{K}_{4}\right)=$ Pemberian akrilamida sebanyak $50 \mathrm{mg} / \mathrm{kgBB}$ selama 4 hari dan dipelihara selama 4 hari, kemudian diberi ekstrak bawang putih berumbi tunggal sebanyak $1000 \mathrm{mg} / \mathrm{kgBB}$ selama 14 hari

Tahap in vivo dilakukan dengan memberikan bubuk bawang putih sesuai dosis yang telah ditetapkan. Sebanyak 36 mencit jantan (Mus Musculus) dengan berat badan 25-35 g dan berumur 3-4 minggu dipuasakan selama 20 jam.

Mencit dimasukkan ke dalam kandang kolektif suhu $20-25^{\circ} \mathrm{C}$. Mencit diadaptasikan selama 1 minggu dan diberi makan dan minum secara ad libitum. Pada waktu pengambilan data, 3 ekor mencit jantan pada masing-masing perlakuan dinekropsi untuk di uji perubahan

\section{HASIL}

Dari hasil penelitian yang sudah dilakukan terhadap uji golongan sulfida pada bawang putih majemuk dan bawang putih berat badan dan histopatologi paru-paru, kemudian dibuat preparat histologi dengan pewarnaan histokimia hematoksilin eosin (HE).

\section{Berat badan}

Berat awal badan mencit ditimbang pada hari ke- 8 adaptasi. Mencit dibagi sesuai kelompok masing-masing dan dilakukan perlakuan. Pada hari ke-30, berat akhir badan mencit ditimbang kembali dan kemudian dibandingkan perubahannya.

\section{Histopatologi paru-paru}

Setelah dilakukan perlakuan pada mencit, selanjutnya mencit dikurbankan (euthanasia) pada minggu ke-3 setelah pemberian ekstrak, kemudian dilakukan pembedahan mencit untuk pengambilan organ paru. Paru yang telah diambil kemudian dimasukkan ke dalam pot berisi formalin $10 \%$. Setelah itu, pembuatan preparat histopatologi paru menggunakan pewarnaan Hematoxylin $\operatorname{Eosin}(\mathrm{HE})$.

Pengamatan preparat histopatologi paru dilakukan di bawah mikroskop dengan perbesaran 100x untuk melihat perubahan gambaran histologi sel paru, sedangkan untuk menghitung jumlah fokus tumor pada bronkiolus dan septa alveoli dengan perbesaran 10x preparat slide dan dilakukan penilaian jumlah total fokus tumor (Ayunda, 2014).

tunggal dan pengaruh pemberian kedua jenis bawang putih ini terhadap kondisi berat dan kondisi paru-paru mencit dapat di lihat pada Tabel dan Gambar dibawah ini.

Tabel 1. Analisis Golongan Sulfide Bubuk Bawang Putih dengan GC-MS

\begin{tabular}{lll}
\hline \multirow{2}{*}{ Jenis Bubuk Bawang Putih } & \multicolumn{2}{c}{ Jenis Sulfida } \\
\cline { 2 - 3 } Majemuk & \multicolumn{1}{c}{ GC } & \multicolumn{1}{c}{ MS } \\
& Diallyl disulphide & Allicin \\
& Trisulfide, methyl-2-propenyl & Methyl allyl sulfide \\
& Allyl trisulfide & Diallyl disulfide \\
& & Diallyl trisulfide \\
& & Diallyl tetrasulfide \\
Tunggal & Methyl sulfany \\
& & Thiophene \\
& Disulfide, di-2-propenyl & Propene sulfide \\
& & Methyl allyl trisulfide \\
& & Diallyl disulfide \\
\hline
\end{tabular}


Tabel 2. Berat Badan Mencit Akhir Pengujian In Vivo

\begin{tabular}{lcc}
\hline Perlakuan & $\begin{array}{c}\text { Berat badan akhir setelah } \\
\text { 22 hari pengujian }(\mathrm{g})\end{array}$ & $\begin{array}{c}\text { Kenaikan berat badan dari awal } \\
\text { pengujian }(\%)\end{array}$ \\
\hline Kontrol & $34,667 \pm 1,1547$ & 100,00 \\
Kontrol negatif & $36,333 \pm 1,5275$ & 6,06 \\
Majemuk $500 \mathrm{mg} / \mathrm{kgbb}$ & $37,000 \pm 10,583$ & 60,60 \\
Majemuk $1000 \mathrm{mg} / \mathrm{kgbb}$ & $36,333 \pm 2,0817$ & 51,51 \\
Tunggal $500 \mathrm{mg} / \mathrm{kgbb}$ & $41,000 \pm 8,0000$ & 87,87 \\
Tunggal $1000 \mathrm{mg} / \mathrm{kgbb}$ & $34,000 \pm 5,2915$ & 36,00 \\
\hline
\end{tabular}

Tabel 3. Persen Mortalitas Pengujian In Vivo pada Mencit Percobaan

\begin{tabular}{llll}
\hline \multicolumn{1}{c}{ Perlakuan } & Jumlah mencit awal & Jumlah mencit mati & Mortalitas $(\%)$ \\
\hline Kontrol & 4 & 1 & 25,0 \\
Kontrol negatif & 8 & 5 & 62,5 \\
Majemuk 500 mg/kgbb & 6 & 3 & 50 \\
Majemuk 1000 mg/kgbb & 6 & 0 & 0 \\
Tunggal 500 mg/kgbb & 6 & 3 & 50 \\
Tunggal 1000 mg/kgbb & 6 & 1 & 16,7 \\
\hline
\end{tabular}

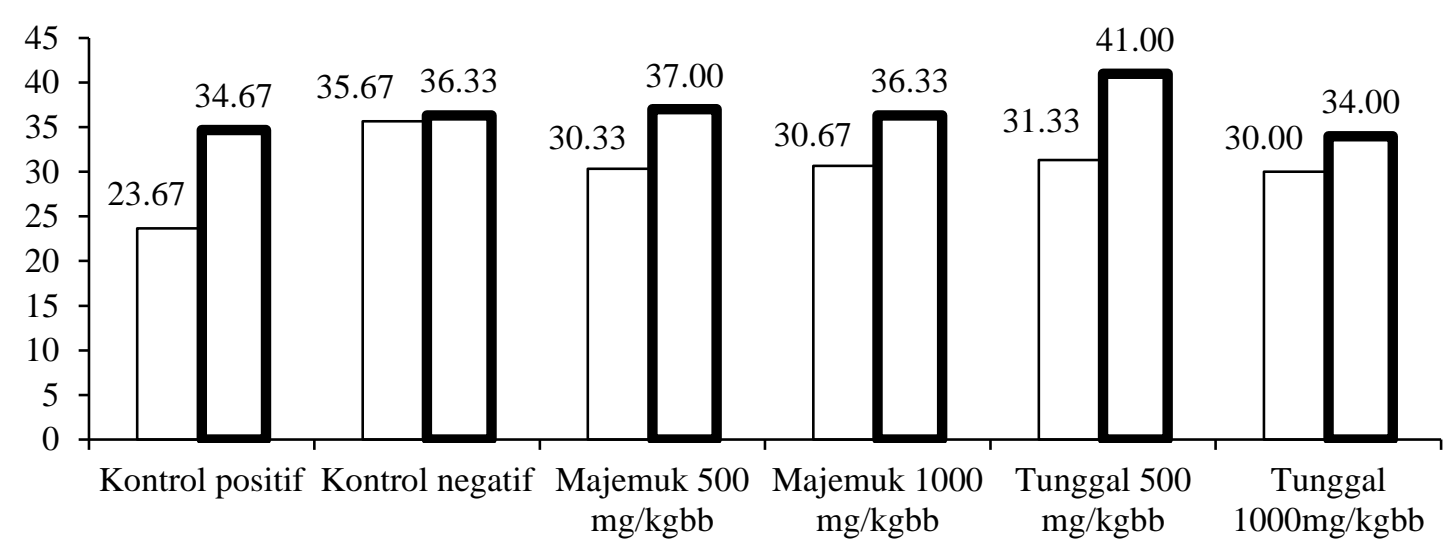

Gambar 1. Kenaikan Berat Badan Mencit Awal dan Akhir Pengujian 


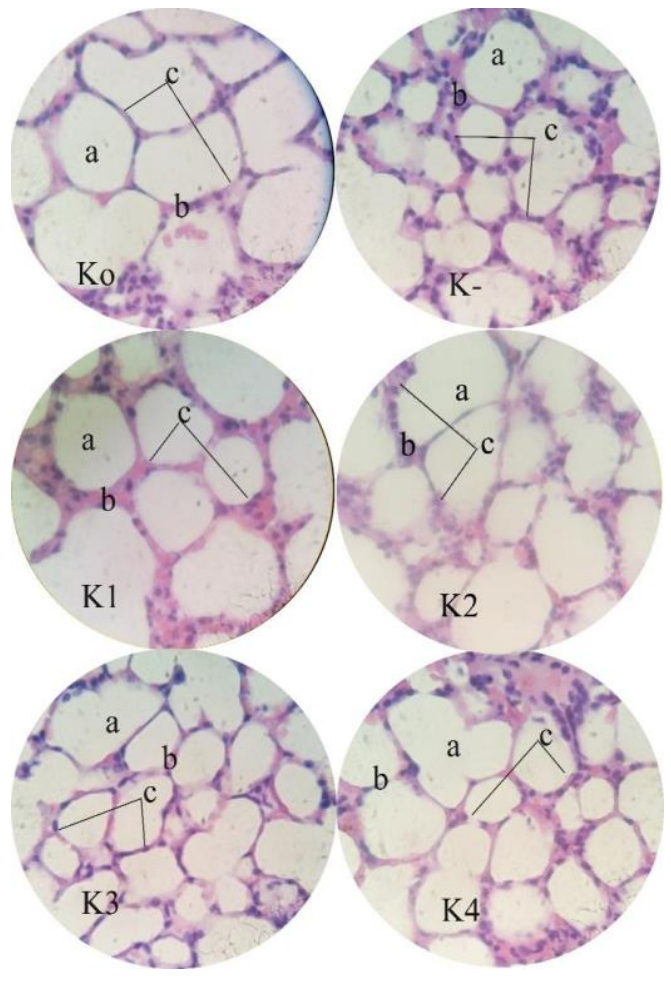

Gambar 2. Histologi Alveolus

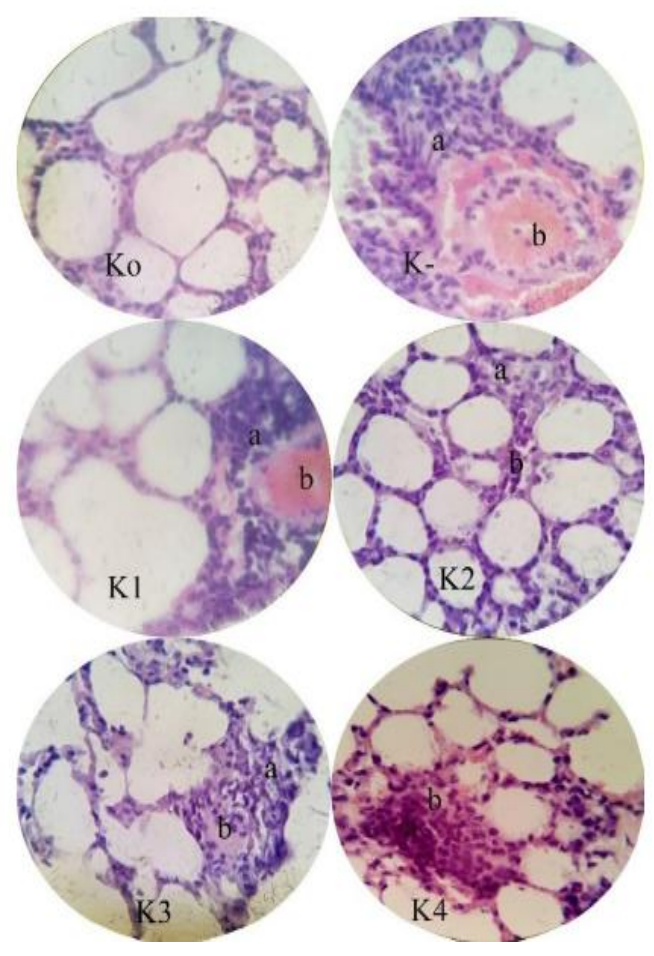

Gambar 4. Histologi Paru-Paru

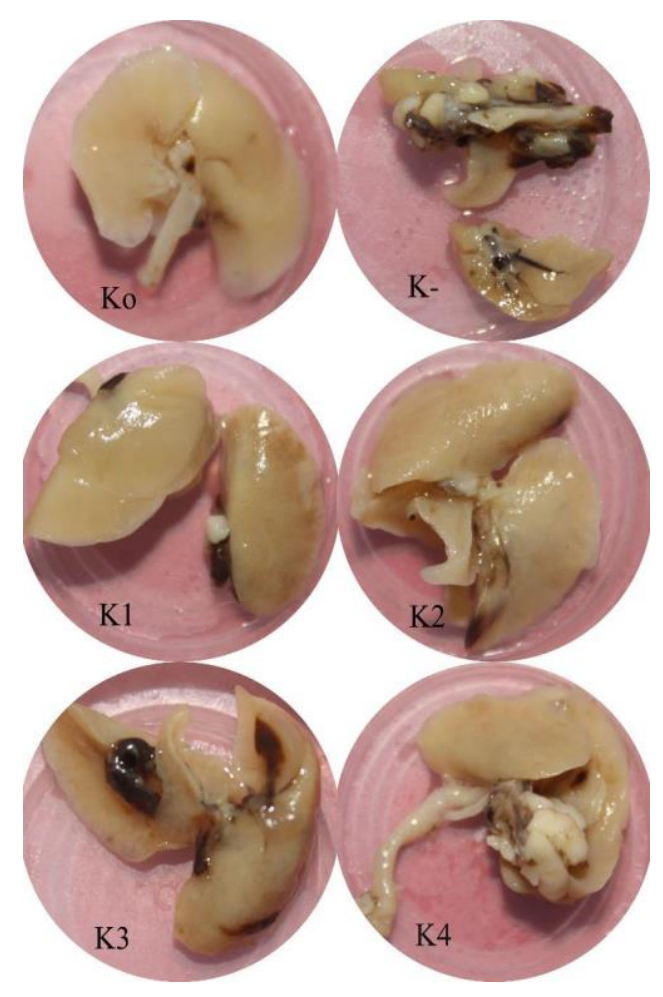

Gambar 3. Warna Paru-paru Mencit

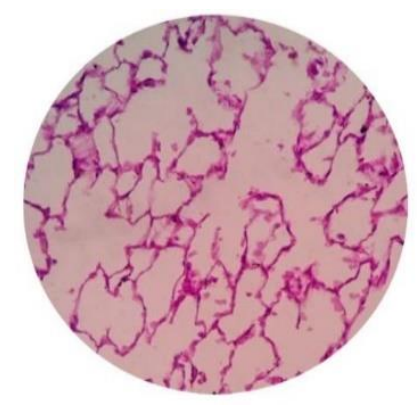

Gambar 5. Histologi Normal 


\section{PEMBAHASAN}

Hasil analisa senyawa sulfida dengan GC pada bubuk bawang majemuk dan bubuk bawang tunggal dapat dilihat pada pada Tabel 1. Tabel 1 menunjukkan bahwa golongan sulfida bubuk bawang majemuk lebih tinggi dan lebih banyak jenisnya dibandingkan dengan bubuk bawang tunggal. Hal yang paling berpengaruh pada perbedaan jumlah senyawa sulfida ini adalah kondisi lingkungan saat penanaman bawang dan kandungan kadar air.

Menurut Kaisar (2014) bahwa bawang putih tunggal termasuk tanaman yang pertumbuhannya tidak sempurna karena kondisi lingkungan yang tidak sesuai seperti kondisi iklim, tanah maupun suhu lingkungan, akibatnya hanya mampu membentuk tunas utama dan menekan pertumbuhan tunas-tunas bakal siung sehingga hanya tumbuh satu tunas dan membentuk umbi utuh yang kecil.

Hasil spektrum massa pada Tabel 1 menunjukkan bahwa bubuk bawang putih membuktikan bahwa bubuk bawang putih kering memiliki jenis senyawa sulfida yang lebih banyak dibandingkan bawang putih segar yang dibandingkan dengan hasil penelitian Junedi (2018) menyimpulkan bahwa identifikasi dengan GC-MS pada hasil ekstraksi bawang putih ditemukan hanya dua jenis senyawa sulfida yaitu diallyl disulfide dan allyl sulfide.

Senyawa-senyawa organosulfur tersebut memiliki peran masing-masing yang sangat penting dalam menghambat proliferasi atau kerusakan sel serta memacu aktivitas apoptosis sel sehingga memungkinkan sel-sel tubuh menghancurkan sel kanker akibat induksi akrilamida pada mencit percobaan. .

Dari Tabel 3 dapat dilihat bahwa persen mortalitas pada kelompok kontrol negatif dengan perlakuan disuntik akrilamida dosis $50 \mathrm{mg} / \mathrm{kgBB}$ selama 4 hari sebesar 62,5\%, sedangkan pemberian ekstrak bubuk majemuk dosis 1000 $\mathrm{mg} / \mathrm{kgBB}$ terendah, yaitu $0 \%$ yang berarti tidak ada mencit yang mati, sehingga pemberian ekstrak bubuk bawang dengan dosis 1000 $\mathrm{mg} / \mathrm{kgBB}$ dapat dikatakan efektif dalam meningkatkan daya tahan mencit terhadap proliferasi sel paru-paru akibat penyuntikan senyawa karsinogenik yaitu akrilamida.

Pada uji pemberian ekstrak etanol bubuk bawang putih yang paling mendekati kenaikan berat badan normal yaitu pemberian ekstrak bubuk bawang putih tunggal dosis 500 $\mathrm{mg} / \mathrm{kgBB}$ dengan kenaikan $87,87 \%$ dan yang paling jauh yaitu pemberian ekstrak bubuk bawang putih tunggal dosis $1000 \mathrm{mg} / \mathrm{kgBB}$ dengan kenaikan $36 \%$, sedangkan pemberian ekstrak bubuk bawang putih majemuk baik dosis
$500 \mathrm{mg} / \mathrm{kgBB}$ maupun $1000 \mathrm{mg} / \mathrm{kgBB}$ hampir mendekati kenaikan berat normal.

Kenaikan berat badan pada pemberian ekstrak bubuk bawang terjadi karena senyawa metabolit sekunder pada bubuk bawang mampu meminimalkan pengaruh akrilamida terhadap penurunan nafsu makan mencit. Adapun perbedaan kenaikan berat badan awal dan akhir setiap kelompok dapat dilihat pada Gambar 1 .

Paru-paru kelompok kontrol (Ko) atau tanpa perlakuan berwarna putih. Warna lebih coklat kehitaman dan lebih banyak bintik hitam ditemui pada kelompok negatif dengan perlakuan diinduksi akrilamida $50 \mathrm{mg} / \mathrm{kgBB}$ selama 4 hari.

Hal ini juga ditemui pada penelitian Triana et al. (2013) bahwa paru-paru kelompok kontrol tanpa perlakuan adalah putih kemerahan namun pada mencit kelompok pemaparan asap rokok tembakau murni memiliki paru-paru yang berwarna gelap dan terdapat bercak hitam pada permukaan paru-paru. Perbedaan warna paruparu yang diperoleh dari hasil penelitian dapat dilihat pada Gambar 2.

Menurut Santoso et al. (2004) dalam Triana et al. (2013), pada saat merokok, berbagai bahan kimia terserap masuk dan dalam jangka panjang dapat menyebabkan penghambatan kerja paru. Zat tar yang mengandung akrilamida serta senyawa kimia berbahaya lainnya akan menyelimuti paru-paru yang secara bersamaan akan mempengaruhi kinerja kantung udara (alveolus) dalam paru-paru.

Perubahan kinerja alveolus ditandai dengan perubahan pada lebar lumen alveolus, membran alveolus, dan hubungan antar alveolus yang dapat dilihat pada Gambar 2 dan berdasarkan penelitian terdahulu gambaran histologis alveolus normal dapat dilihat pada Gambar 5.

Dari kelompok perlakuan, pemberian ekstrak bubuk bawang majemuk $1000 \mathrm{mg} / \mathrm{kgbb}$ (K2) memiliki lebar lumen alveolus yang paling besar. Hal ini membuktikan bahwa kelompok perlakuan ini memiliki pengaruh terbesar dalam menghambat senyawa akrilamida yang menyebabkan kanker paru-paru, karena semakin lebar lumen alveolus maka semakin normal alveolus paru-paru sesuai dengan penelitian Arobi (2010) yang menyatakan bahwa lebar alveolus dilihat dari jarak antara dinding sel alveolus satu dengan alveolus lainnya. Semakin luas jarak antara alveolus, maka semakin bagus keadaan alveolus paru-paru mencit.

Adanya nodul tumor dan pendarahan pada paru-paru mencit dapat dilihat pada Gambar 4. Timbulnya nodul tumor pada kelompok negatif (K-) karena terjadi proliferasi sel epitel 
berlebih dari membran alveolus yang menyebabkan lumen alveolus menyempit dan bentuknya tidak beraturan akibat pecahnya sel. Menurut Ayunda (2014) adanya aktivitas senyawa karsinogenesis dapat dilihat melalui munculnya pertambahan jumlah sel epitel pada bronkiolus serta septa alveoli dan inti sel yang tampak tidak teratur.

Pada pemberian ekstrak bubuk bawang putih majemuk maupun tunggal dengan dosis $1000 \mathrm{mg} / \mathrm{kgBB}$ susunan sel pada nodul tumor tidak terlalu rapat dan proliferasi sel mampu dihambat, sehingga semakin tinggi dosis ekstrak yang diberikan maka semakin efektif penghambatan proliferasi sel pembentuk nodul tumor. Hasil penelitian dari Knowles \& Milner (2001) menunjukkan bahwa efektivitas antiproliferasi dan antitumor pada bawang putih disebabkan oleh kandungan organosulfur dan bekerja lebih efektif pada jaringan usus, kulit, dan paru-paru.

\section{KESIMPULAN}

Analisa kandungan golongan sulfida bubuk bawang putih dengan GC-MS diperoleh hasil bahwa bubuk bawang majemuk memiliki golongan sulfida lebih banyak dibandingkan bubuk bawang tunggal. Hasil penelitian secara in vivo membuktikan bahwa ekstrak bubuk bawang putih berpengaruh dalam menghambat proliferasi sel paru-paru akibat induksi akrilamida. Kelompok perlakuan K2 dengan pemberian ekstrak bubuk bawang majemuk dosis $1000 \mathrm{mg} / \mathrm{kgBB}$ paling efektif dalam menghambat proliferasi sel paru-paru karena mengandung senyawa sulfida terbanyak sehingga memiliki aktivitas antikanker tertingggi dan terbukti secara mikroskopis.

\section{SARAN}

Setiap individu yang terpapar asap rokok disarankan mengkonsumsi bawang putih majemuk satu siung per hari untuk mencegah proliferasi sel pada saluran pernafasan akibat senyawa karsinogen akrilamida dari rokok. Perlu dilakukan penelitian lanjutan mengenai efektivitas senyawa antikanker bawang putih terhadap fokus tumor paru-paru dari hasil pemaparan asap rokok secara langsung dengan jangka waktu yang lebih lama dan dianalisa secara kuantitatif.

\section{DAFTAR PUSTAKA}

Arobi, I. 2010. Pengaruh Ekstrak Jahe Merah (Zingiber officinale Rosc) terhadap Perubahan Pelebaran Alveolus ParuParu Tikus (Rattus norvegicus) yang Terpapar Allethrin. Skripsi. Malang:
Universitas Islam Negeri Maulana Malik Ibrahim.

Ayunda, R. F. 2014. Pola Waktu Pemberian Ekstrak Rimpang Kunyit Putih (Curcuma Zedoaria) terhadap Histopatologi Paru Mencit (Mus Musculus) yang Diinduksi Benzo[a]piren. Skripsi. Surabaya: Universitas Airlangga.

Deutsche Welle. 2015. Dilema Rokok di Indonesia: Menyelamatkan Petani atau Kesehatan Penduduk, (Online), http://www.dw.com.html (Diakses 20 Juni 2019).

Junedi, I. 2018. Identifikasi Allisin pada Bawang Putih (Allium sativum L.) Secara Kromatografi Gas Spektrometri Massa (GCMS). Skripsi. Semarang: Universitas Wahid Hasyim.

Kaisar, I. 2014. Pertumbuhan Eksplan Bawang Putih (Allium sativum L.) pada Beberapa Konsentrasi Sukrosa dan Arang Aktif. Skripsi. Bengkulu: Universitas Bengkulu.

Knowles L. M., \& Milner J. A. 2001. Possible Mechanism by Which Allyl Sulfides Suppresses Neoplastic Cell Proliferation. Journal of Nutrition, 131: 1061S-1066S.

Lagnado, J. 2001. Extraction of allicin: The Active Ingredient In Garlic, (Online), http://www.scienteacherprogram.org/pa ges/garlic.html (Diakses 20 Juni 2019).

Lisiswanti, R., \& Haryanto, F. T. 2017. Allicin pada Bawang Putih (Allium sativum L.) sebagai Terapi Alternatif Diabetes Melitus Tipe 2. Majority, 6:31-35.

Liu, C., Yang, X., Yao, Y., Huang, W., Sun, W. and Ma, Y. 2014. Determination of Antioxidant Activity in Garlic (Allium sativum) Extracts Subjected to Boiling Process In Vitro. Journal of Food and Nutrition Research, 11:383-387.

Nawangsih, E. F., Safitri, U. H., Apliani, D., Nur'aini, F. \& Noviyanti, N. D. 2015. GAS-API (Garlic as Apoptosis Inducer) : Studi In Vivo Kemampuan Ekstrak Etanolik Bawang Putih (Allium Sativum) dalam Menginduksi Sel Apoptosis pada Tumor Praganas (Displasia) Lidah. BIMKGI. 3:20-27. 
Santoso, HB. 2000. Bawang Putih. Edisi ke-12. Kanisius, Yogyakarta.

Seyedzadeh A., Hashemi F., and Soleimani A. 2012. Relationship between Blood Pressure and Passive Smoking in Elementary School Children. Iran $J$ Pediatr, 22: 351- 356.

Triana, N., Ilyas, S. \& Hutahaean, S. 2013. Gambaran Histologis Pulmo Mencit Jantan (Mus Musculus) setelah Dipapari Asap Rokok Elektrik. Jurnal Saintia Biologi. 1:1-7.

Yee, D. 2019. Investigation of Chemical Composition, Antimicrobial and Antioxidant Activities of Allium Wallichii Kunth (Garlic) Bulb. American Scientific Research Journal for Engineering, Technology, and Sciences (ASRJETS), 54:30-41.

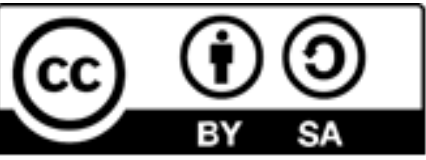

